\title{
Comparative RNA-seq analysis reveals dys-regulation of major canonical pathways in ERG-inducible LNCaP cell progression model of prostate cancer
}

\author{
Parameet Kumar ${ }^{1}$, Joyeeta Chakraborty ${ }^{2}$, Gauthaman Sukumar ${ }^{1,3}$, Clifton Dalgard $^{1,4}$, \\ Raghunath Chatterjee $^{2}$ and Roopa Biswas ${ }^{1}$ \\ ${ }^{1}$ Department of Anatomy, Physiology and Genetics, Uniformed Services University of the Health Sciences, Bethesda, MD, USA \\ ${ }^{2}$ Human Genetics Unit, Indian Statistical Institute, Kolkata, India \\ ${ }^{3}$ Collaborative Health Initiative Research Program, Henry Jackson Foundation, Bethesda, MD, USA \\ ${ }^{4}$ The American Genome Center, Uniformed Service University of the Health Sciences, Bethesda, MD, USA \\ Correspondence to: Roopa Biswas, email: roopa.biswas@usuhs.edu \\ Parameet Kumar, email: parameet.kumar.ctr@usuhs.edu
}

Keywords: RNAseq; prostate cancer; LNCaP cells; ERG; mRNA

Received: December 29, $2018 \quad$ Accepted: May 30, 2019 Published: July 02, 2019

Copyright: Kumar et al. This is an open-access article distributed under the terms of the Creative Commons Attribution License 3.0 (CC BY 3.0), which permits unrestricted use, distribution, and reproduction in any medium, provided the original author and source are credited.

\section{ABSTRACT}

Prostate Cancer ( $\mathrm{CaP}$ ) is the second leading cause of cancer related death in USA. In human CaP, gene fusion between androgen responsive regulatory elements at the 5'-untranslated region of TMPRSS2 and ETS-related genes (ERG) is present in at least $50 \%$ of prostate tumors. Here we have investigated the unique cellular transcriptome associated with over-expression of ERG in ERG-inducible LNCaP cell model system of human CaP. Comprehensive transcriptome analyses reveal a distinct signature that distinguishes ERG dependent and independent CaP in LNCaP cells. Our data highlight a significant heterogeneity among the transcripts. Out of the 526 statistically significant differentially expressed genes, 232 genes are up-regulated and 294 genes are down-regulated in response to ERG. These ERG-associated genes are linked to several major cellular pathways, cell cycle regulation being the most significant. Consistently our data indicate that ERG plays a key role in modulating the expression of genes required for $\mathrm{G1}$ to $\mathrm{S}$ phase transition, particularly those that affect cell cycle arrest at $\mathbf{G 1}$ phase. Moreover, cell cycle arrest in response to ERG appears to be promoted by induction of p21 in a p53 independent manner. These findings may provide new insights into mechanisms that promote growth and progression of $\mathrm{CaP}$.

\section{INTRODUCTION}

Prostate cancer $(\mathrm{CaP})$ is the most commonly diagnosed male malignancy and a leading cause of cancer related deaths in USA [1-3]. Despite current advances in $\mathrm{CaP}$ research, there is a need for novel therapeutic targets for human $\mathrm{CaP}[4]$. ERG is the most commonly overexpressed oncogene in $\mathrm{CaP}[5]$ and arises from a fusion between androgen receptor regulated promoter of TMPRSS2 and ETS-related genes (ERG) [6]. Various studies have reported that $50 \%$ of radical prostatectomy samples have a fusion of the TMPRSS2 with the coding sequences of ERG [7]. Subsequent studies established that the variability in the frequency of TMPRSS2:ERG fusion gene ranges from $27 \%$ to $79 \%$ [8]. Thus, there is a tremendous interest in dissecting the molecular mechanism by which the TMPRSS2-ERG fusion promote progression of $\mathrm{CaP}$ [9]. The discovery of the TMPRSS2:ERG gene fusion shifts the current paradigm in cancer genomics from experimental to bioinformatics approaches [7]. Here we report a unique cellular transcriptome associated with over-expression of ERG in ERG-inducible LNCaP cell model system of human CaP. 
Over the decade a number of new cutting-edge technologies, including microarray-based transcriptomic analyses, have emerged as important tools for understanding the pathogenesis of $\mathrm{CaP}$ [10]. These technologies have added strongly to our understanding of the growth and development of human cancer [11], but have several major limitations. The recent advent of nextgeneration RNA sequencing (RNA-seq) technologies has overcome some of these limitations, and have thus created a whole new avenue for comprehensive transcriptome analysis [12]. RNA-seq is a powerful tool for studying gene expression and for analyzing changes in gene structure at the transcript level. Recently, RNA-seq has been increasingly used to explore and analyze the genetic factors of prostate cancers, such as fusion genes, somatic mutations, noncoding RNAs, alternative splicing events, and mutations in prostate cancer cell lines and tumors [13]. RNA-seq also has been used to dissect the factors involved in the conversion to androgen independence as well as radio-sensitization [14]. RNA-seq has led to the discovery of additional ETS fusion and has been used for analyzing novel genomic rearrangements to interrogate the whole cellular transcriptome [15].

To analyze the role of ERG over-expression in $\mathrm{CaP}$ development and progression, we performed genomewide transcriptome profiling (RNA-seq) in $\mathrm{LNCaP}$ cell model system. Here we report the identification of novel differentially expressed genes (DEGs) associated with ERG over-expression in CaP. Our data suggest that the DEGs associated with key pathways are involved in cell cycle regulation. Our study demonstrates the role of ERG in reducing cell proliferation by modulating the expression of genes required for G1 to S phase transition, and thereby resulting in cell cycle arrest at G1 phase. We have also identified functionally important canonical pathways regulated by ERG, which may lead to novel therapeutic targets for ERG-associated CaP.

\section{RESULTS}

\section{Effect of ERG on gene expression in LNCaP cells}

To identify the gene signature associated with over-expression of ERG and to gain insight into the TMPRSS2-ERG gene fusion, we performed RNA-seq analysis. We employed tetracycline/doxycycline-mediated ERG-inducible LNCaP cell system designated as LnTE3 (LNCaP-lentivirus TMPRESS2:ERG3, inducible) cells $[2,16]$. LnTE3 cells exhibits increased expression of ERG protein upon addition of doxycycline (Figure 1A) and a corresponding increase in expression of TMPRSS2-ERG mRNA (Figure 1B). LnTE3 cells that were not treated with doxycycline, and hence do not express ERG, served as a negative control. The total number of sequenced reads range from 16-23 million in ERG over-expressing cells (ERG + ) and 10-22 million in ERG- LnTE3 cells
(Supplementary Table 1). Approximately, $90 \%$ of the reads in each sample are aligned to the human genome (hg19).

Density plot showing the distribution of RNA-seq read counts (FPKM) of ERG- (orange area) and ERG+ (blue area) samples indicate that majority of the genes have similar distribution of RNA-seq read counts (grey area) (Figure 1C). Gene expression was determined by the number of reads uniquely mapped to the specific gene and the total number of uniquely mapped reads in the sample. Then fragments per kilobase of transcript per million mapped reads (FPKM), which takes into account both the gene length and sequencing depth on read count, was calculated. Figure 1D depicts the scatter plot of the transcripts with $\left|\log _{10} \mathrm{FC}\right| \geq 2(q$-value $\leq 0.05)$ in the ERG+ cells compared to ERG- cells. It is evident that ERG induces an alteration in gene expression profile in these LnTE3 cells.

We have identified a total of 526 statistically significant DEGs in ERG + cells compared to ERG- LnTE3 cells (Supplementary Data 1). Approximately 44\% (232) of the differentially expressed genes are up regulated, while $56 \%$ (294) of the DEGs are down regulated in ERG+ LnTE3 cells compared to the ERG- control cells. Hierarchical clustering of 526 DEGs indicated two distinct clusters for ERG+ and ERG- LnTE3 cells (Supplementary Figure 1).

For further downstream analysis, we considered a set of 117 DEGs with $\left|\log _{2} \mathrm{FC}\right| \geq 2$ in ERG+ compared to ERG- LnTE3 cells. As depicted in Figure 2, hierarchical clustering of these 117 genes include a total of 7 clusters, among which 5 clusters are dominant. Z score was calculated for each of the 117 genes. The top genes that are induced by ERG include TFF1, RSAD2, OASL, IFIT2, IFIT1, S100P, IFIT2, REG4, RARRES3, IFIT3, ARHGDIB, ANXA1, PRSS23, IGFBP3, APOL3, FOS and $S 100 A 9$. While those genes that are suppressed by over-expression of ERG include APLN, CCL2, SLC30A4, LCP1, GLYATL2, FAM111B, TARP, RLN1, ESCO2 and TRPM8 (Supplementary Data 1).

\section{Functional analyses of differentially expressed genes}

Next we performed in silico analyses of the significant DEGs in ERG+ LnTE3 cells compared to ERG- control cells ( $\geq 2.0$ fold change cut-off; $q$-value $\leq$ $0.05)(n=526$; Supplementary Data 1$)$ using Ingenuity Pathway Analysis (IPA). Table 1 summarizes the ERGinduced top five diseases and disorders; and include Cancer ( $p$-value range $=1.20 \mathrm{E}-04-4.96 \mathrm{E}-27)$, Organismal injury and abnormalities ( $p$-value range $=1.20 \mathrm{E}-04-4.96 \mathrm{E}$ 27 ), Reproductive system disease ( $p$-value range $=1.20 \mathrm{E}$ $04-4.96 \mathrm{E}-27$ ), Respiratory disease ( $p$-value range $=9.96 \mathrm{E}$ 05-1.33E-16), Gastrointestinal disease ( $p$-value range $=1.16 \mathrm{E}-04-1.25 \mathrm{E}-13)$. The top ranked bio-functions significantly affected by ERG over-expression include 
Cell Cycle ( $p$-value range=1.42E-04-3.98E-33, z-score $=-0.947)$, Cellular Growth and Proliferation ( $p$-value range $=1.23 \mathrm{E}-04-1.68 \mathrm{E}-31, \mathrm{z}$-score $=-3.881)$, Cellular Development ( $p$-value range $=1.23 \mathrm{E}-04-3.73 \mathrm{E}-27$, $\mathrm{z}$-score $=-3.463)$, Cell Death and Survival ( $p$-value range $=1.37 \mathrm{E}-04-3.91 \mathrm{E}-27, \mathrm{z}$-score $=-2.125)$, and Cellular Assembly and Organization ( $p$-value range $=1.42 \mathrm{E}-04$ 4.46E-24, z-score $=-0.378$ ).

Subsequent to analyses of cellular processes affected by ERG expression, we analyzed canonical pathways enriched with ERG over-expression. The topfive statistically significant canonical pathways affected by increased expression of ERG include, Cell Cycle control of chromosomal replication ( $p$-value $=2.69 \mathrm{E}-16$, z-score $=\mathrm{NaN}$ ), Role of CHK proteins in Cell Cycle checkpoint control $(p$-value $=3.16 \mathrm{E}-11, \mathrm{z}$-score $=0.707)$, Cell Cycle: G2/M DNA damage checkpoint regulation ( $p$-value = 1.34E-09, z-score $=1.508$ ), Role of BRCA1 in DNA
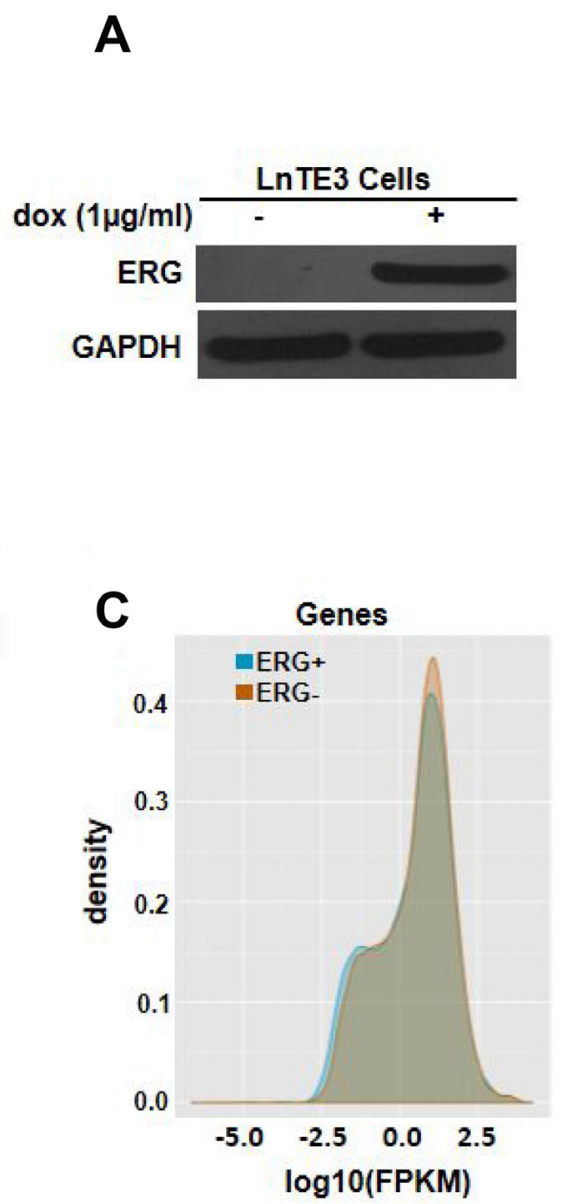

damage response $(p$-value $=4.05 \mathrm{E}-08, \mathrm{z}$-score $=-1.0)$ and Estrogen-mediated S-phase entry ( $p$-value $=5.51 \mathrm{E}-08$, z-score $=-2.82$ ) (Figure 3, Table 2).

Cell cycle control of chromosomal replication was observed as the top canonical pathway affected by ERG over-expression and indicate slow $\mathrm{S}$ phase in response to DNA damage. Our data also illustrate that the 14 genes (ORC6, ORC1, MCM7, MCM6, MCM5, MCM4, MCM3, MCM2, CHEK2, CDT1, CDK2, CDC45, $C D C 7$ and $C D C 6$ ) involved in this cellular process are all significantly down-regulated by ERG (Figure 4A, Table 2). Estrogen-mediated S-phase entry was also amongst the top canonical pathways found to be enriched in ERG+ LnTE3 compared to ERG- control cells (Figure 4B, Table 2). As shown in Figure 4B, increased expression of ERG suppresses the expression of $c-M Y C, E 2 F$, $S K P 2, C D K 2, C D C 2$ as well as cyclin $A$ and cylcin $E$. Moreover, we find that ERG induction also induces p21
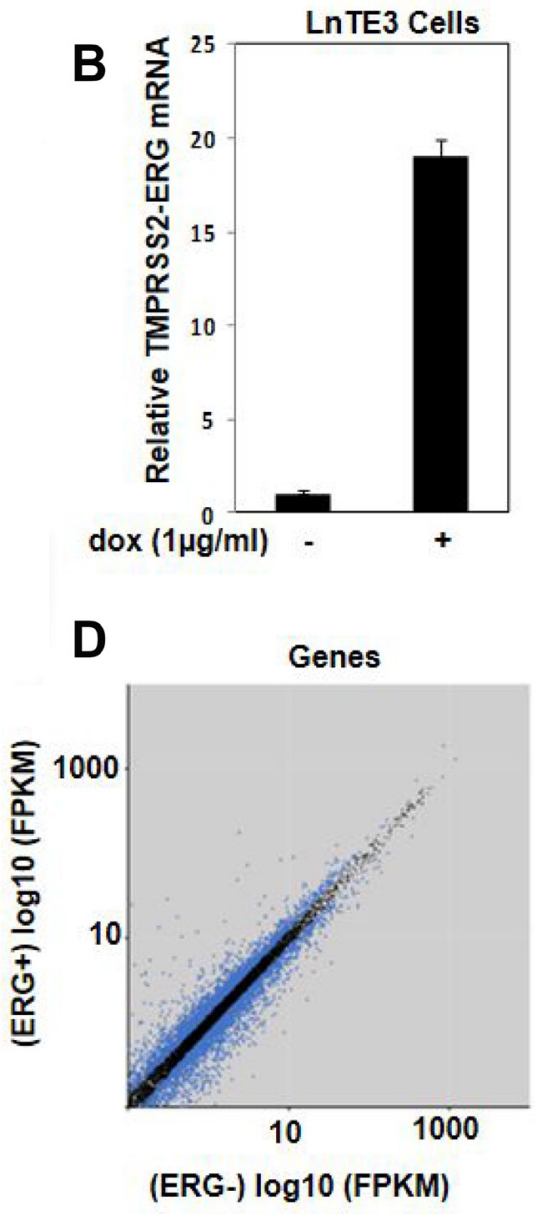

Figure 1: Transcriptomic analysis of ERG-inducible LNCaP cells. LnTE3 cells were treated with doxycycline $(1 \mu \mathrm{g} / \mathrm{ml})$ for 72 hours. ERG expression was analyzed by (A) immunoblot and (B) real-time PCR. The data is representative of three or more independent experiments. (C) The graph depicts the distribution and expression of all annotated genes (y-axis) and the intensity of their expression (x-axis as $\log 10$ (FPKM)) as obtained by global RNA-Seq analysis. (D) Scatter plot indicates the expression of significant genes $(q$-value $<0.05)$ in blue dots under the two experimental conditions, with the x-axis representing the FPKM values for ERG-and the y-axis representing the FPKM values for ERG+ samples. 
expression (also known as CDKN1A or p21 $1^{\mathrm{WAF} 1 / \mathrm{ClP} 1}$ ). Since ERG modulates the expression of majority of the genes involved in cell cycle regulation (Table 2, Figure 3, Figure $4 \mathrm{~A}$ and $4 \mathrm{~B}$ ) we performed cell cycle progression studies in LnTE3 cells. LnTE3 cells were treated with dox $(1 \mu \mathrm{g} / \mathrm{ml})$ to induce ERG and synchronized by serum deprivation. We observe that $24 \mathrm{~h}$ after synchronization, the fraction of cells in the S-phase was reduced (from 31\% to 9\%) in ERG+ LnTE3 cells as compared to control ERGLnTE3 cells (Figure 5A), indicating that over-expression of ERG results in a slower cell cycle progression. We further performed proliferation assays over a 2 to 5 day time course. As depicted in Figure 5B we find that high ERG significantly reduces proliferation of LnTE3 cells. Collectively, our data indicate that ERG plays a key role in modulating the expression of genes required for G1 to $\mathrm{S}$ phase transition, resulting in the cell cycle arrest at G1 phase in LnTE3 cells (Figure 5A).

\section{Gene networks affected by ERG over-expression}

The DEGs were further analyzed for regulatory biological relationships mediated by the ERG overexpression. Table 3 lists the top five gene networks with highest score and focus molecules associated with over-expression of ERG. The top two major networks include 29 focus molecules each (Table 3, Figure 6A and $6 \mathrm{~B})$. The roles and diseases related to Network I are cellular assembly and organization, DNA replication, recombination, and repair, Cell cycle and those related to Network II are Cell cycle, Hematological system development and function, Hematopoiesis (Figure 6A and $6 \mathrm{~B})$. In Network I, the genes that are up-regulated include PRSS23, CUX1, PHF1, TP5313, PSCA and SLC20A2 (shown in the red). Moreover, the different Cyclins
(CCNA2, CCNE2 and Cyclin E) which play a role in cell cycle G1/S transition are down-regulated in response to ERG as illustrated in Network I. Network II reveals MYC as one of the focus molecules. The key genes that are down regulated by ERG include $M Y C, N K X 3-1, M Y B L 2$, $T O P 2 A$ and $E 2 F 1$. Those genes that are up-regulated by ERG induction include $L G M N, F B X O 2$, NOSIP, SSBP2, $Y B X 3$, STOML1, NME7, CMPK2 and CLEC3B.

In the third network, there are 27 focus molecules involved in Cell cycle, Cellular assembly and organization, DNA replication, recombination, and repair network. Majority of the genes involved in this network are suppressed by ERG-induction except ZFP36L1 (Table 3). ERG also modulates the expression of FOS and PCNA, which are focus molecules in Network IV that includes DNA replication, recombination, and repair, cancer, Organismal injury and abnormalities (Table 3). The fifth network includes DNA replication, recombination, and repair, Connective tissue disorders, and Developmental disorder. Interestingly, majority of the genes involved in these networks are down-regulated in ERG+ cells compared to ERG- LnTE3 cells.

\section{Expression and validation of DEGs}

Our RNA-seq data indicate that TP53, CDKN1A and $\mathrm{E} 2 \mathrm{~F} 1$, are the top molecules from upstream regulator analyses (generated by IPA). CDKN1A, E2F1 and c-MYC were also significantly enriched in one of the top canonical pathways "estrogen-mediated S-phase entry" (see Figure 4B). Moreover, E2F1, c-MYC and NKX3-1 appeared as major focus molecules of Network II (see Figure 5B). ERG induction in LnTE3 cells significantly alters the expression of TP53, CDKN1A, E2F1, c-Myc and NKX3.1 genes. While c-MYC, TP53, E2F1 and NKX3-1 were suppressed

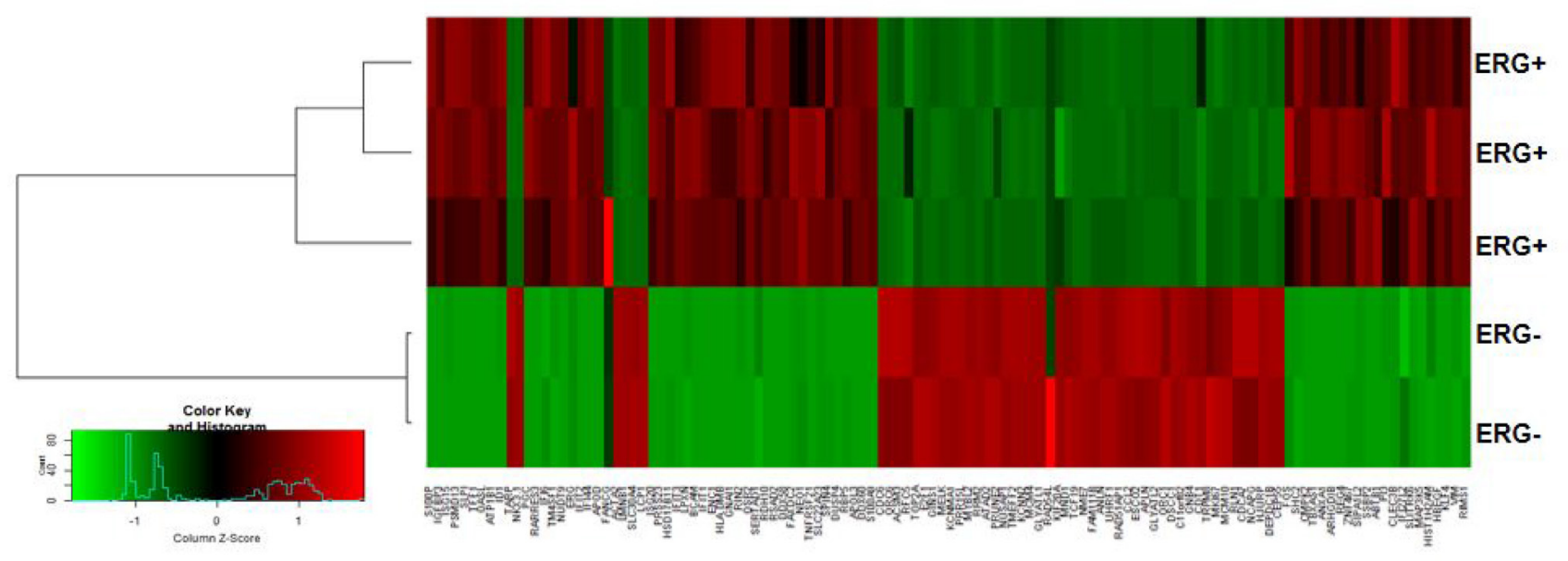

Figure 2: ERG-associated transcripts in CaP cells. Hierarchical clustering of transcripts significantly altered in expression can distinguish between ERG+ and ERG- LnTE3 cells. The heat map indicates the expression level of the transcripts significantly altered in ERG+ compared to ERG- LnTE3 cells: red represents increased expression, while green represents reduced expression. The expression levels are continuously mapped on the color scale provided at the bottom of the figure. 
Table 1: Top diseases and bio-functions enriched by differentially expressed genes with increased expression of ERG in LnTE3 cells

\begin{tabular}{|c|c|c|c|}
\hline \multicolumn{4}{|c|}{ Top diseases } \\
\hline Diseases and Disorders & \multicolumn{2}{|c|}{$p$ value range } & Molecules \\
\hline Cancer & \multicolumn{2}{|c|}{$1.20 \mathrm{E}-04-4.96 \mathrm{E}-27$} & 449 \\
\hline Organismal Injury and Abnormalities & \multicolumn{2}{|c|}{$1.20 \mathrm{E}-04-4.96 \mathrm{E}-27$} & 449 \\
\hline Reproductive System Disease & \multicolumn{2}{|c|}{$1.20 \mathrm{E}-04-4.96 \mathrm{E}-27$} & 264 \\
\hline Respiratory Disease & \multicolumn{2}{|c|}{$9.96 \mathrm{E}-05-1.33 \mathrm{E}-16$} & 95 \\
\hline Gastrointestinal Disease & \multicolumn{2}{|c|}{$1.16 \mathrm{E}-04-1.25 \mathrm{E}-13$} & 345 \\
\hline \multicolumn{4}{|c|}{ Top Bio functions } \\
\hline Molecular and Cellular Functions & $p$ value range & z-score & Molecules \\
\hline Cell Cycle & $1.42 \mathrm{E}-04-3.98 \mathrm{E}-33$ & -0.947 & 171 \\
\hline Cellular Growth and Proliferation & $1.23 \mathrm{E}-04-1.68 \mathrm{E}-31$ & -3.881 & 259 \\
\hline Cellular Development & $1.23 \mathrm{E}-04-3.73 \mathrm{E}-27$ & -3.463 & 219 \\
\hline Cell Death and Survival & $1.37 \mathrm{E}-04-3.91 \mathrm{E}-27$ & -2.125 & 225 \\
\hline Cellular Assembly and Organization & $1.42 \mathrm{E}-04-4.46 \mathrm{E}-24$ & -0.378 & 127 \\
\hline
\end{tabular}

Top five enriched disease and biological functions as analyzed with Ingenuity Pathway Analysis software in the experimental dataset. z-score, measure of predicted changes, increased (positive z-score) or decreased (negative z-score). Molecules, number of genes in the dataset, which are represented in the top disease or Bio-functions.

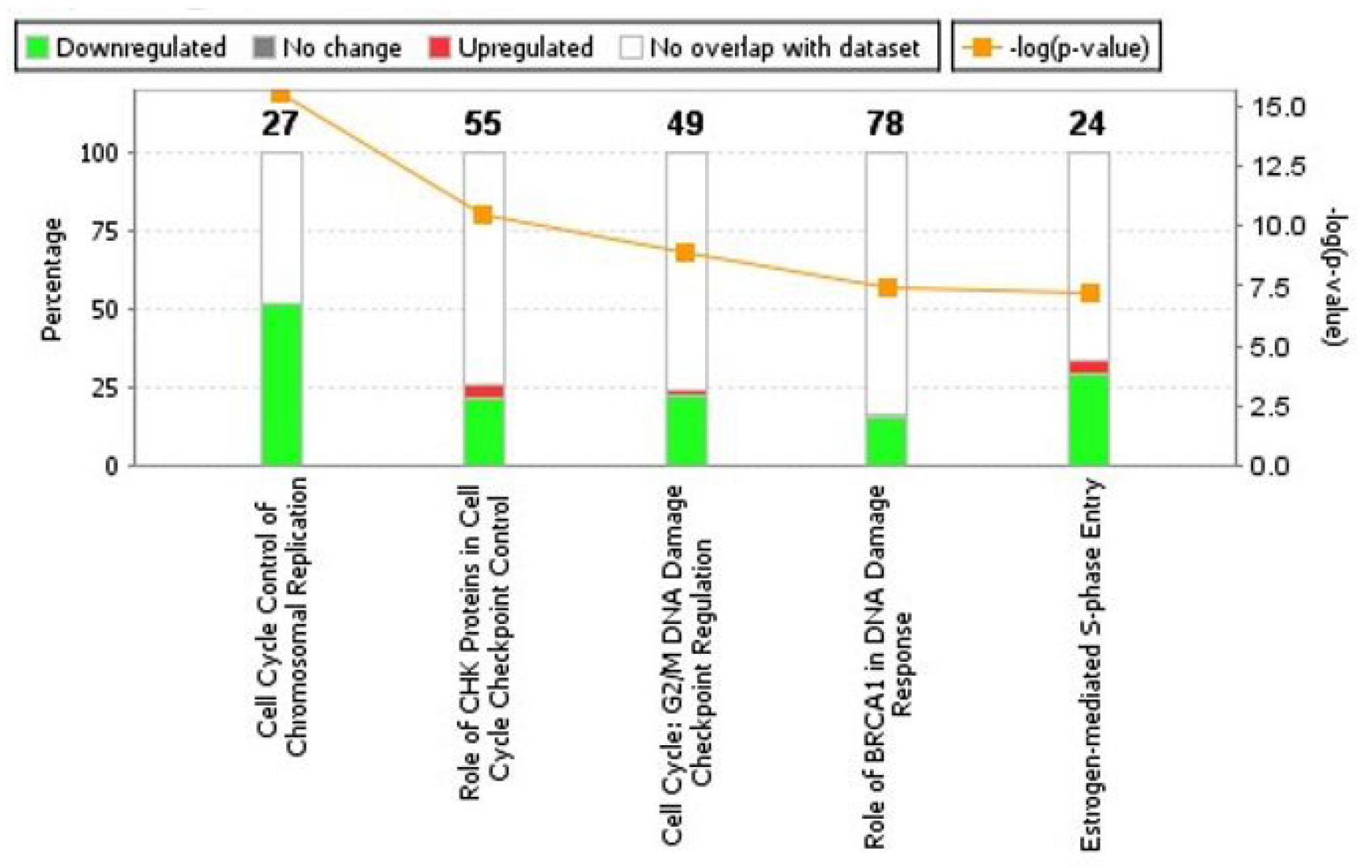

Figure 3: Analyses of canonical pathways in ERG-inducible LnTE3 cells. Top five canonical pathways enriched by DEGs (differentially expressed genes) are depicted. Canonical pathways significantly altered by increased ERG expression were generated by IPA. The orange line represents a ratio of regulated proteins to all proteins in the pathway. The stacked bar chart for each canonical pathway displays the number of genes that were significantly up-regulated (red), and down-regulated (green). The molecules/genes in a given pathway that were not found in our list of significantly regulated genes are termed unchanged (grey) or not overlapping with our dataset (white). The numerical value at the top of each bar represents the total number of genes/molecules in the canonical pathway. 
Table 2: Top canonical pathways enriched by differentially expressed genes obtained with increased expression of ERG in LnTE3 cells

Top canonical pathways

\begin{tabular}{lccc}
\hline Pathways & $\boldsymbol{p}$ value & z-score & Overlap, ratio \\
\hline Cell Cycle Control of Chromosomal Replication & $2.69 \mathrm{E}-16$ & NaN & $51.9 \%(14 / 27)$ \\
Role of CHK Proteins in Cell Cycle Checkpoint Control & $3.16 \mathrm{E}-11$ & 0.707 & $25.5 \%(14 / 55)$ \\
Cell Cycle: G2/M DNA Damage Checkpoint Regulation & $1.34 \mathrm{E}-09$ & 1.508 & $24.5 \%(12 / 49)$ \\
Role of BRCA1 in DNA Damage Response & $4.05 \mathrm{E}-08$ & -1.0 & $16.7 \%(13 / 78)$ \\
Estrogen-mediated S-phase Entry & $5.51 \mathrm{E}-08$ & -2.82 & $33.3 \%(8 / 24)$ \\
\hline
\end{tabular}

Significantly enriched canonical pathways in the experimental dataset with ERG induction in LnTE3 cells are shown. z-score; is a measure of predicted change (activated or reduced) of the pathways. NaN, not a number. Overlap, ratio; percentage of genes in the dataset, as represented in the pathway. Numbers in brackets show number of gene in the data set to the total number of genes in the pathway in the reference gene set.

by ERG induction in LnTE3 cells, CDKN1A was upregulated (Figure 7A). Validation of the expression of these genes was further performed by immunoblot analyses. As shown in Figure 7B, protein expression data exhibits a trend that is consistent with that obtained from RNA-seq.

\section{GO term analysis of differentially expressed genes}

To determine the proportion of input genes in ERG+ LnTE3 cells involved in a particular cellular process or function compared to that in ERG- control cells, we performed Gene Ontology (GO) analysis of the DEGs present in the 5 dominant clusters (described in Figure 2). GO enrichment analysis (FDR $<0.1$ and Fold Enrichment $\geq 2$ ), identified many processes and functions that are regulated by ERG, including regulation of cell cycle (FDR $=2.53 \mathrm{E}-10)$, Cell cycle G1/S phase transition $(\mathrm{FDR}=$ $0.002663973)$, Regulation of transcription involved in $\mathrm{G} 1 / \mathrm{S}$ transition of mitotic cell cycle $(\mathrm{FDR}=0.000780178)$, and cell cycle phase transition $(\mathrm{FDR}=0.007444829)$ (Figure 8).

\section{DISCUSSION}

Prostate cancer is a multifactorial disease caused by a series of genetic alterations [17]. The TMPRSS2:ERG gene fusion is detected in $50 \%$ of the CaP patients [18]. To investigate the characteristics of ERG-dependent and ERG-independent prostate cancer, RNA from these two groups was subjected to RNA sequencing. We identified a total of 526 differentially expressed genes that are significantly altered by increased expression of ERG in LNCaP cells. These differentially expressed genes are associated with many pathways and functions. Our data suggest that the most significant effect is on cell cycle regulation. Consistently, we also observe enrichment of major cell cycle-related canonical pathways with increased expression of ERG in $\mathrm{CaP}$ cells.
The top genes that are elevated with over-expression of ERG and are known to be regulators of cancer phenotype include TFF1, S100P, REG4, ARHGDIB, ANXA1, PRSS23, IGFBP3, APOL3, FOS and S100A9. TFF1 (Trefoil factor-1) also known as $p S 2$ [19], is the most up-regulated gene induced by ERG. This gene belongs to the family of trefoil factors, that are classical estrogen-regulated genes [20] and is overexpressed in several types of cancers including prostate cancer [21, 22]. TFF1 enhances cell migration and invasion [23] and has been shown to be a marker of hormone responsiveness in tumors [24]. Previous reports indicate that patients with advanced prostate cancer have significantly higher plasma concentrations of TFF1 [25]. High S100P expression is observed in several types of cancers and has been shown to mediate tumor growth, drug resistance, and metastasis [26]. Additionally, S100P is regulated by androgen [27], and high S100P promotes prostate cancer progression [28]. Consistent with previous studies [29], our data also indicate that ERG induces the expression of S100P. We also detected high expression of REG4 in ERG + compared to ERG- LnTE3 cells. REG4 has been shown to be a prognostic factor in clinically localized prostate cancer [30] and a promising marker of hormone refractory metastatic prostate cancer [31]. REG4 has been shown to enhance metastasis in gastric carcinomas [32] and also contributes to invasiveness in pancreatic [33] and colorectal carcinoma [34]. ARHGDIB also known as RhoGDI2 has been identified as a proto-oncogene and is up regulated in multiple human cancer [35, 36]. RhoGDI2 also regulates epithelial-mesenchymal transition, which is responsible for invasiveness during tumor progression [37]. Annexin A1 (ANXA1) is overexpressed in the invasive stages of prostate cancer [38] and is involved in the acquisition and maintenance of stem-like/aggressive features in prostate cancer [39]. Serine protease PRSS23 is known to be associated with tumor progression in various types of cancers and is co-expressed with estrogen receptor $\alpha(\mathrm{ER} \alpha)[40]$. IGFBP3 levels are significantly elevated in 

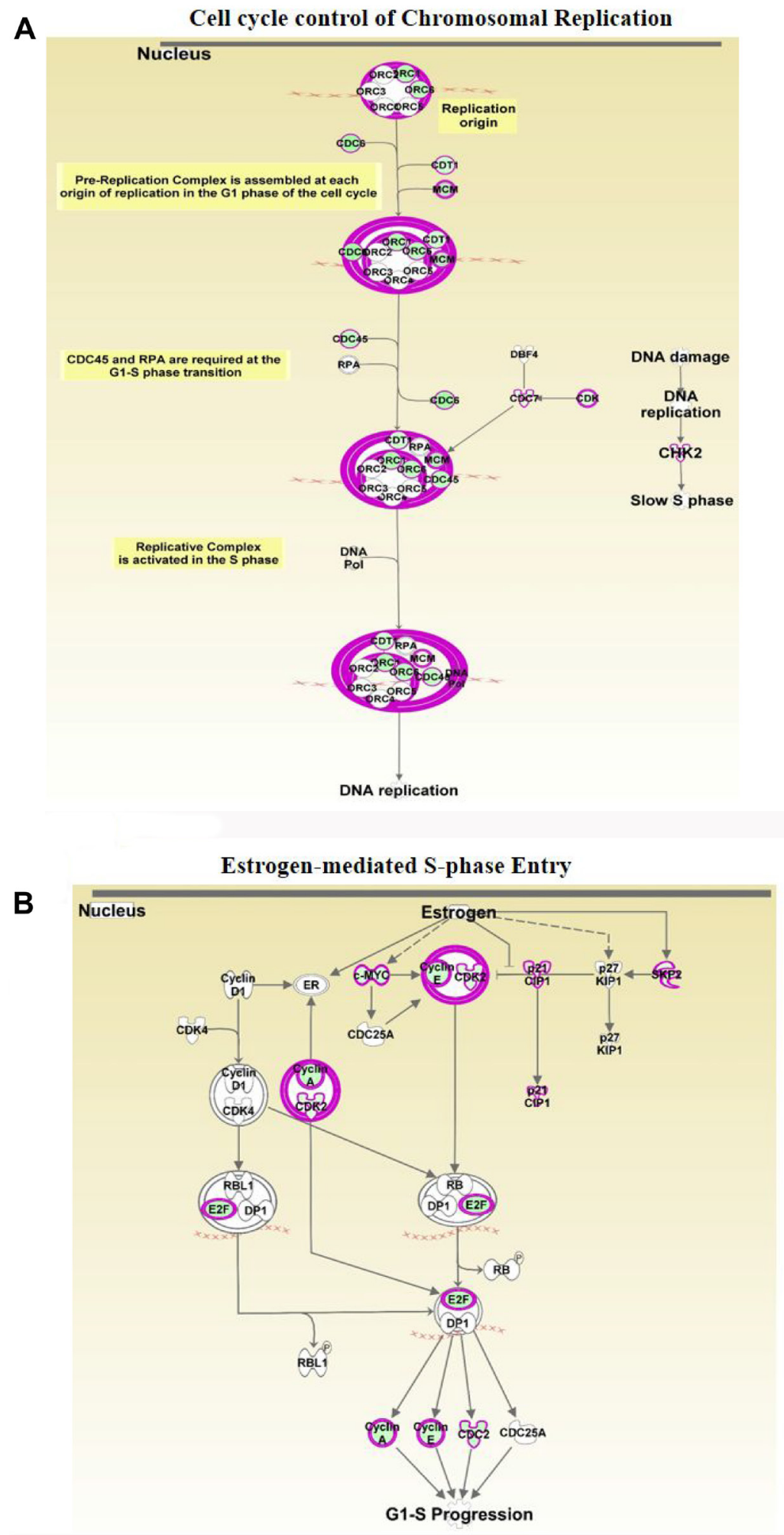

Figure 4: Analyses of ERG-associated cellular pathways. Differentially expressed genes obtained by RNA-seq in the ERGinducible LnTE3 cells were analyzed using IPA. Canonical pathway analysis revealed several significantly deregulated pathways including: (A) Cell Cycle Control of Chromosomal Replication and (B) Estrogen-Mediated S-phase Entry. Majority of the focus molecules are present in the differentially expressed genes. Significantly up-regulated gene are indicated in red and down-regulated genes are in green, and those present within our data set but not significant are shown in grey. Arrows indicate gene products which were found to be oppositely regulated. 
prostate cancer patients urine [41] and is consistent with our data. Moreover, a case-control study has shown the association between a SNP within the APOL3 locus and prostate cancer risk [42].

The genes that are suppressed by over-expression of ERG in LnTE3 cells includes APLN, CCL2, SLC30A4, LCP1, GLYATL2, FAM111B, TARP, RLN1, ESCO2 and TRPM8. Our data indicate that GLYATL2, an ETV1 target gene $[43,44]$, is reduced with ERG over-expression in CaP cells. FAM111B common variants are associated with prostate cancer susceptibility in the Japanese population [45]. TRPM8 variant $\alpha$ is generally overexpressed in prostate cancer [46] but contrary to this our data show that it is suppressed in ERG over-expressing LnTE3 cells. RLN1 is known to form a fusion with RLN2 in LNCaP cells as well as in normal and prostate cancer tissues [47]. We find that ERG causes reduced expression of RLN1. SLC30A4, another gene whose expression is suppressed by ERG, a zinc transporter (ZnT4), has been shown to promote the progression of $\mathrm{CaP}$ from early prostate disease to invasive prostate cancer [48].

Disruption of various signaling pathways is a characteristic feature of tumors $[49,50]$. Our data illustrate the enrichment of key cellular signaling pathways involved in the carcinogenic process. The top canonical pathways altered with ERG over-expression are mainly associated with Cell cycle control. (Table 1). The top upstream regulators that emerge from IPA analyses include TP53, CDKN1A, E2F1 and CCND1 molecules. The precise switch from $\mathrm{G} 1$ to $\mathrm{S}$ phase is vital for cell proliferation and its mis-regulation promotes oncogenesis [51]. We find that ERG suppresses the expression of $51.9 \%$ of the genes involved in cell cycle control of chromosomal replication, including origin recognition complex (ORC1 and ORC4) as well as initiation factors, including CDT1, CDC6 and Mcm, essential for the assembly of the prereplication complex. ORC-depleted cells have been shown to be arrested in G1 phase [52]. Moreover, it has been established that deregulation of CDC6 expression poses a serious risk of carcinogenesis and its down-regulation inhibits cell proliferation and promotes apoptosis [53]. $\mathrm{CHK}$ is required for checkpoint mediated cell cycle arrest in response to DNA damage, and suppression of CHK1 by ETS family members has been shown to promote DNA damage response [54]. Consistently, our data indicate that CHK is suppressed by ERG expression in LnTE3 cells. $\mathrm{Cdc} 45$, an essential protein required for the initiation of DNA replication, is also suppressed by increased
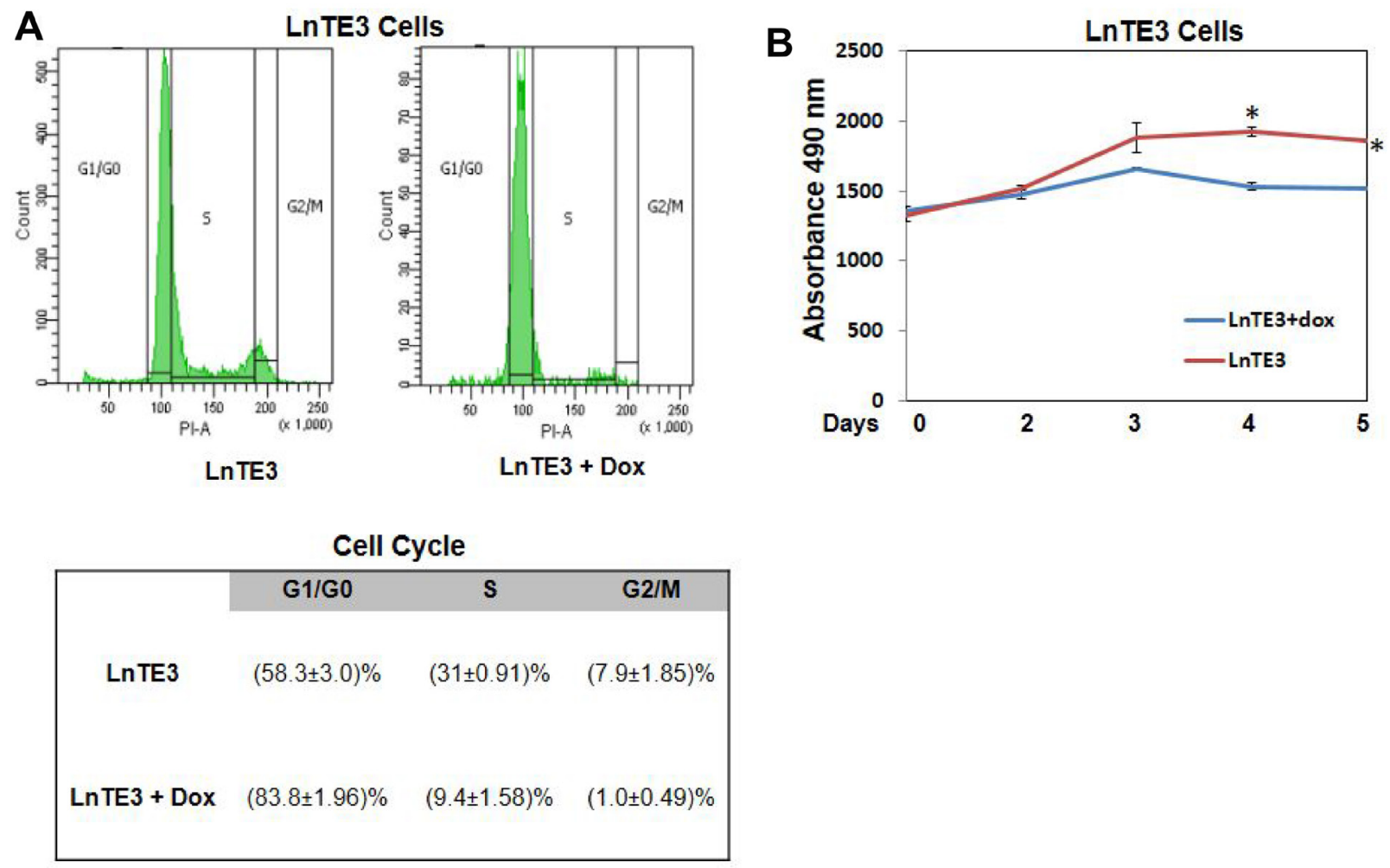

Figure 5: Analyses of cell cycle in ERG-inducible CaP cells. (A) LnTE3 cells were treated with or without doxycycline ( $1 \mu \mathrm{g} / \mathrm{ml}$ ) for $72 \mathrm{hr}$, cells were synchronized by serum deprivation, and cell cycle distribution was analyzed with the help of BD LSR II flow cytometer. The data (mean $\pm \mathrm{SD}$ of three experiments) indicate the relative percentage of cells at G0/G1, S, and G2/M phase of the cell cycle. (B) Cell proliferation assay was performed by measuring cell number over a 2 to 5 day time course. The reported results are the mean of three independent experiments $(p<0.05)$. 


\begin{tabular}{|c|c|c|c|}
\hline Score & $\begin{array}{l}\text { Focus } \\
\text { molecules }\end{array}$ & $\begin{array}{l}\text { Representative differentially expressed genes in ERG+ } \\
\text { LnTE3 cells }\end{array}$ & $\begin{array}{l}\text { Genes function and } \\
\text { description }\end{array}$ \\
\hline 44 & 29 & 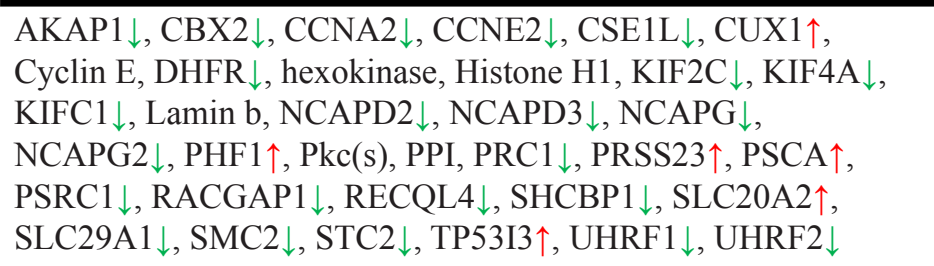 & $\begin{array}{l}\text { Cellular Assembly and } \\
\text { Organization, DNA } \\
\text { Replication, Recombination, } \\
\text { and Repair, Cell Cycle }\end{array}$ \\
\hline 44 & 29 & 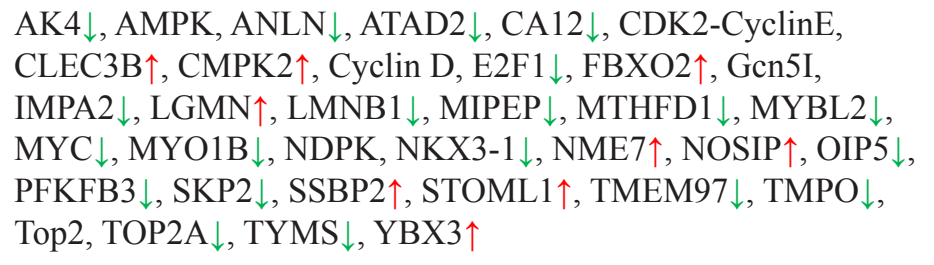 & $\begin{array}{l}\text { Cell Cycle, Hematological } \\
\text { System Development and } \\
\text { Function, Hematopoiesis }\end{array}$ \\
\hline 40 & 27 & 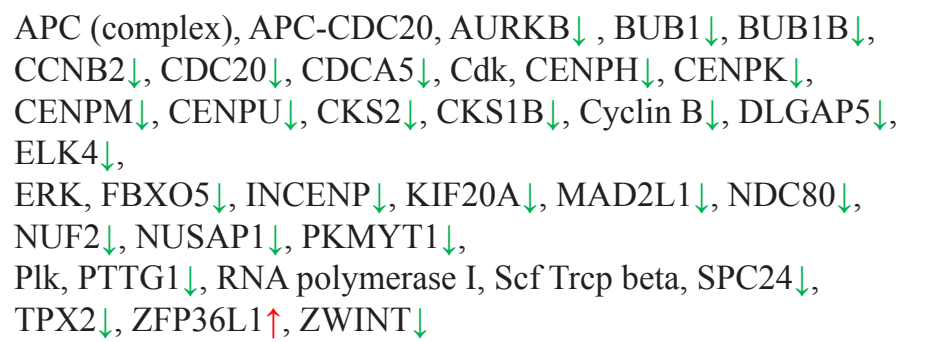 & $\begin{array}{l}\text { Cell Cycle, Cellular Assembly } \\
\text { and Organization, DNA } \\
\text { Replication, Recombination, } \\
\text { and Repair }\end{array}$ \\
\hline 40 & 27 & 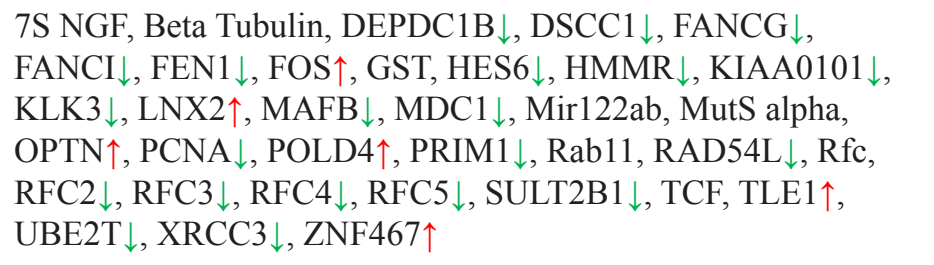 & $\begin{array}{l}\text { DNA Replication, } \\
\text { Recombination, and Repair, } \\
\text { Cancer, Organismal Injury } \\
\text { and Abnormalities }\end{array}$ \\
\hline 33 & 24 & 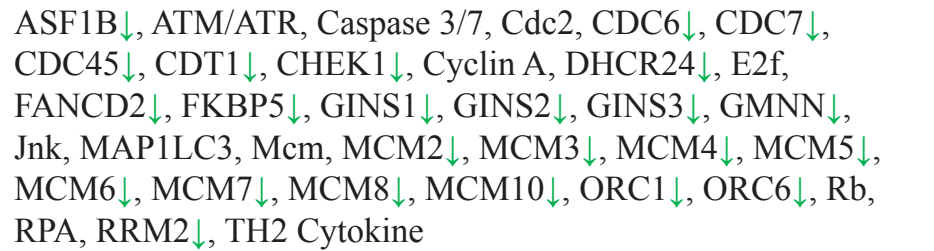 & $\begin{array}{l}\text { DNA Replication, } \\
\text { Recombination, and Repair, } \\
\text { Connective Tissue Disorders, } \\
\text { Developmental Disorder }\end{array}$ \\
\hline
\end{tabular}

Notes: $\uparrow$ upregulation. $\downarrow$ downregulation.

expression of ERG in LnTE3 cells. This is in concurrence with a previous study which demonstrated that increased expression of ERG leads to genomic instability [55].

The transcription factor E2F1 is active during G1 to $\mathrm{S}$ transition and is involved in cell cycle progression. Here we also report the reduced expression of E2F1 with increased expression of ERG in LnTE3 cells. Further analyses also indicate that ERG causes slow $\mathrm{G} 1$ to $\mathrm{S}$ phase transition in ERG+ LnTE3 cells. These findings are consistent with a recent study, which demonstrated that increased ERG expression causes reduced proliferation and accumulation of cells in G1 phase [56]. p2 $1^{\mathrm{WAF} 1 / \mathrm{CIP} 1}$ associates directly with E2F1 and suppresses its transcriptional activity [57]. Our RNA-seq and immunoblot data demonstrate that ERG promotes increased expression of $\mathrm{p} 21^{\mathrm{WAF} 1 / \mathrm{CIP} 1}$ in ERG + LnTE3 cells. p2 $1^{\mathrm{WAF} 1 / \mathrm{CIP} 1}$ is a potent inhibitor of CDK activity and can suppress cell growth and proliferation by blocking cell cycle progression in the G1/S phase transition [58]. Moreover, p21 over-expression has been associated with severe clinical outcome with androgen deprivation therapy in prostate cancer $[59,60]$. Elevated levels of p21 also appears to be associated with invasive phenotype of cancer [28]. Increased p21 expression has been observed in cervical carcinoma, brains tumors and is associated with recurrence and metastasis of ovarian cancer [61-63]. Furthermore, p21 is induced by both p53-dependent and independent mechanisms in response to DNA-damaging agents and is known to induce apoptosis [2, 64, 65]. Since our earlier studies have demonstrated the reduced expression of p53 with increased levels of ERG in CaP cells [2], it appears that in these ERG-inducible LnTE3 

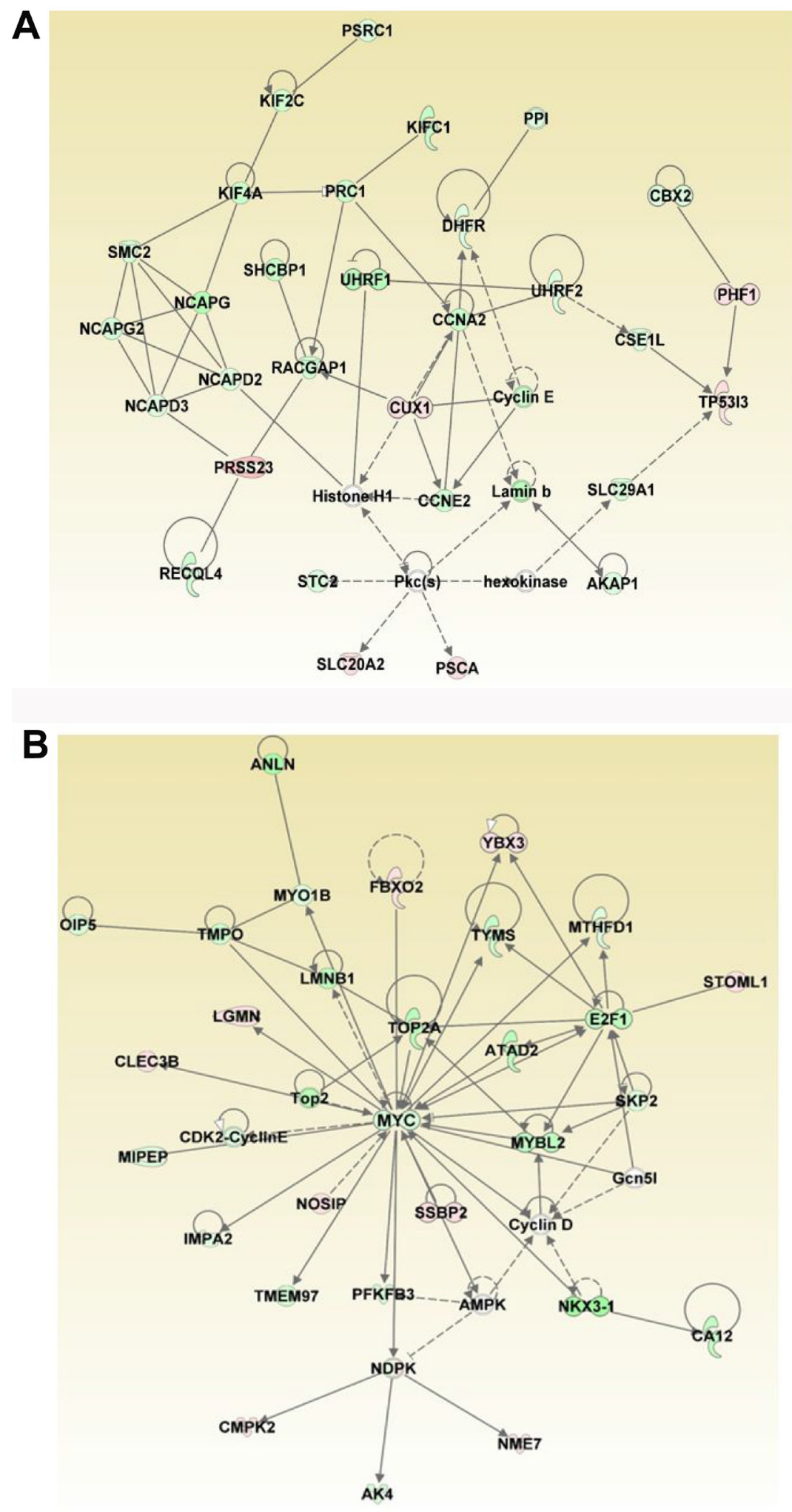

Figure 6: Analyses of ERG-associated networks. Top two gene networks generated by IPA analysis include (A) Cellular Assembly and Organization, DNA Replication, Recombination, and Repair, Cell Cycle and (B) Cell Cycle, Hematological System Development and Function, Hematopoiesis. Majority of the focus molecules are present in differentially expressed genes. Solid arrows represent the genes that interact directly, dotted arrows represent indirect interactions between genes. Network I consists of six down regulated and eight upregulated genes and Network II consists of five down regulated and eight up-regulated genes. 
cells, p21 expression can be regulated independent of $\mathrm{p} 53$. This phenomenon is consistent with previous reports [57, 66]. The up-regulation of p21 expression promoted by increased levels of ERG is clearly important for understanding p53-independent growth arrest. The regulation of $\mathrm{p} 21$ by factors like ERG suggests that it is a more universal cell cycle regulator, as in the present study p21 expression is clearly regulated independent of p53. Moreover, it has been demonstrated that p21 binding to PCNA causes G1 and G2 cell cycle arrest in p53-deficient cells [67]. Thus, ERG appears to play a critical role in p21 induction following DNA damage and is perhaps protecting cells from apoptosis by suppressing p53.

It is well established that increased expression of Myc induces cell cycle progression and its down-regulation impairs cell cycle progression [68]. Myc is suggested to play an important role in the transition from quiescence state to proliferation [69]. It has been shown that Myc disrupts the PCNA-p21 interaction, thus refining p21dependent inhibition of PCNA and DNA synthesis [57]. Here we report that ERG reduces the expression of PCNA and Myc in LnTE3 cells. However, this is contrary to that observed in ERG-positive VCaP cell lines, which have increased Myc expression [70]. Individual cancer cell lines provide a stage of the cancer at the time the biopsy was taken [71]. This variability may be due to the differences in cancer stages in these two different cell lines.

In summary, we observe the enrichment of major canonical pathways with ERG induction in LnTE3 cells. Our data suggest that, the differentially expressed genes in key pathways are associated with cell cycle regulation. Moreover, ERG suppresses $\sim 50 \%$ of the genes required for cell cycle control of chromosomal replication in LnTE3 cells. Thus, the RNA-seq data and cell cycle analyses collectively indicate that ERG plays a key role in modulating the expression of genes required for G1 to $\mathrm{S}$ phase transition, resulting in cell cycle arrest at G1 phase. This seems to be favored by induction of the key cell cycle regulated gene $\mathrm{p} 21^{\mathrm{WAF} 1 / \mathrm{CIP} 1}$. Moreover, the induction of $\mathrm{p} 21^{\mathrm{WAF} 1 / \mathrm{CIP} 1}$ by ERG appears to be independent of p53. Our present data, clearly suggests the role of ERG in reducing proliferation by slowing down G1 to S phase transition in this LNCaP cell model system.

\section{MATERIALS AND METHODS}

\section{Cell cultures and antibodies}

LNCaP cell line was transduced with an inducible lentiviral ERG construct (LNCaP-lentivirus
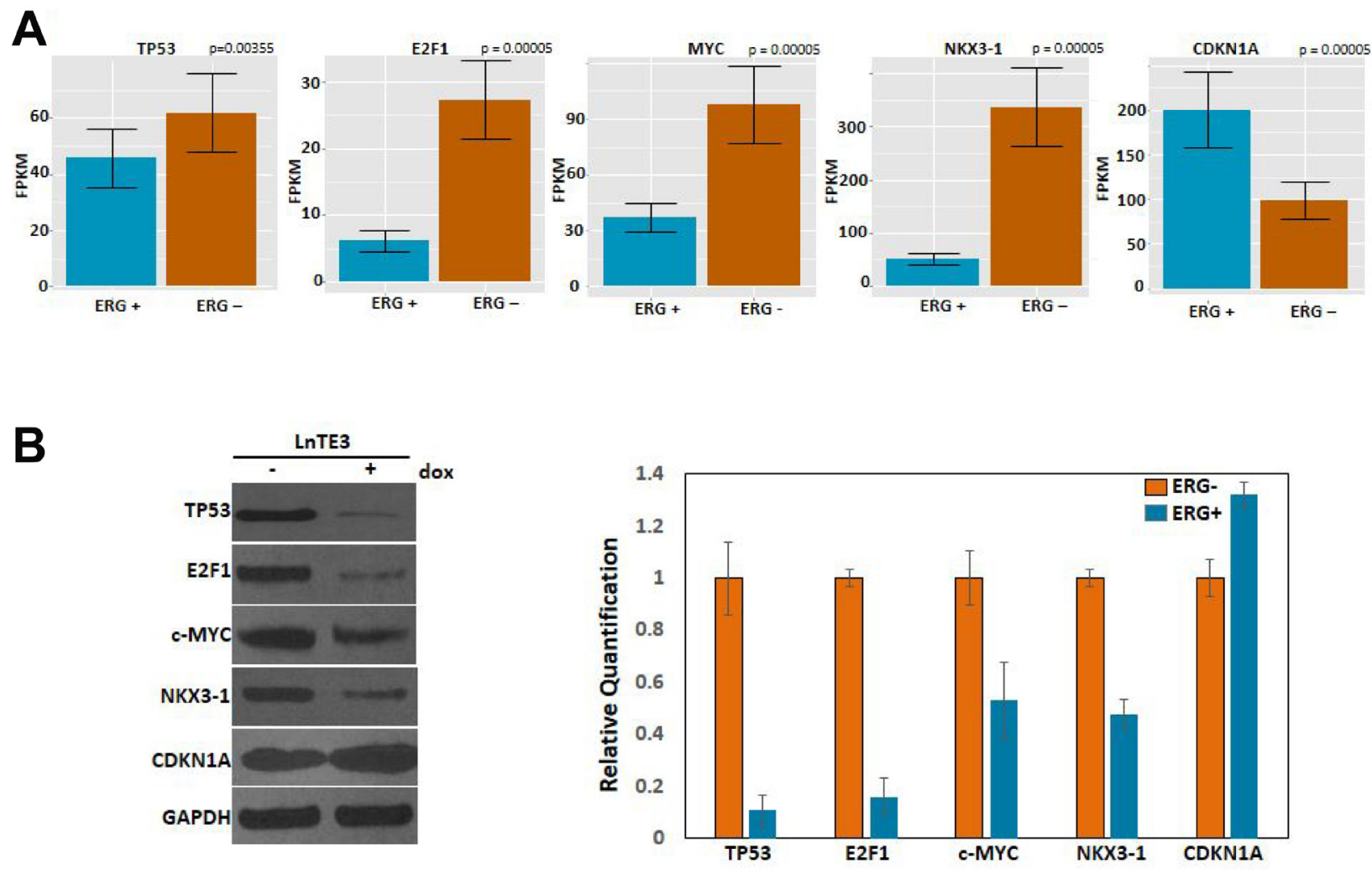

Figure 7: Expression and validation of DEGs. (A) The bar plots represent expression of genes, including TP53, E2F1, c-MYC, NKX3-1 and CDKN1A, in ERG+ as compared to ERG- LnTE3 cells, measured in FPKM. Each gene and transcript expression value is annotated with error bars. (B) Immunoblot analyses of these genes were performed in ERG+ and ERG-LnTE3 cells. Adjacent graph depicts the protein quantification using ImageJ software. The data includes mean and standard deviation from at least three independent experiments. 
TMPRESS2:ERG3 inducible) to establish stable doxycycline-inducible ERG expressing LnTE3 cell line $[2,16]$. The cell lines were cultured in RPMI 1640, supplemented with 10\% Tet System Approved Fetal Bovine Serum (Clontech Laboratories, Inc. Mountain View, CA, USA) and puromycin (Sigma, St. Louis, MO, USA) with or without doxycycline (Dox, $1 \mu \mathrm{g} / \mathrm{ml}$ ) as per requirements and characterized as described [2, 16]. Antibodies used were as follows: anti-GAPDH (Millipore MAB374), antiERG (Abcam ab92513), anti- p21Waf1/Cip1, anti-E2F1 and anti- c-Myc Antibody (Cell Signaling 2946, 3742 and 9402, respectively), anti-p53 DO1 (Santa Cruz biotech, sc126), and anti-NKX3.1 (Biocare Medical SKU 422).

\section{Transcriptome profiling by RNA sequencing}

Total RNA was quantified via a fluorescence dyebased methodology (RiboGreen) on a Spectramax Gemini XPS plate reader (Molecular Devices, Mountain View, CA, USA). RNA integrity was assessed using gel-based electrophoresis on an Experion Automated Electrophoresis System (Bio-Rad, Hercules, CA, USA). All samples used as input for library preparation were RQI $>$ 9.0. Total RNA input of $200 \mathrm{ng}$ was used for library preparation using the TruSeq Stranded mRNA Library Preparation Kit (Illumina, San Diego, CA, USA). Sequencing libraries were quantified by PCR using KAPA Library Quantification Kit for NGS (Kapa, Wilmington, MA, USA) and assessed for size distribution on an Experion
Automated Electrophoresis System. Sequencing libraries were pooled and sequenced on a NextSeq 500 Desktop Sequencer (Illumina) using a NextSeq 500 High Output Kit v2 with 75 bp single-end reads. Raw sequencing data was demuxed using bcl2fastq2 Conversion Software 2.17 before alignment. Quality filtered reads were aligned to the reference human genome (hg19) using TopHat2 [72]. Transcript and gene level quantifications (in FPKM) were estimated using Cufflinks [73].

\section{Identification of differentially expressed genes (DEG)}

Differentially expressed genes (DEGs) were identified using Cuffdiff. Transcripts with at least 10 FPKM in any of the conditions (ERG+ or ERG-) were used for differential gene expression analysis. We found 526 DEGs with a $q$-value $\leq 0.05$, among which 117 genes were differentially expressed in ERG + LnTE3 cells compared to ERG- control cells by at least $\left|\log _{10} \mathrm{FC}\right| \geq 2$. Gene ontology analysis was performed in DAVID GO [74] and Pathway analysis were performed sing Ingenuity Pathway Analysis (QIAGEN Bioinformatics, USA).

\section{Real-time PCR and western blotting}

Total RNA was isolated using the mirVana miRNA Isolation Kit (Invitrogen, AM1560) following the manufacturer's instructions. After RNA extraction, RNA

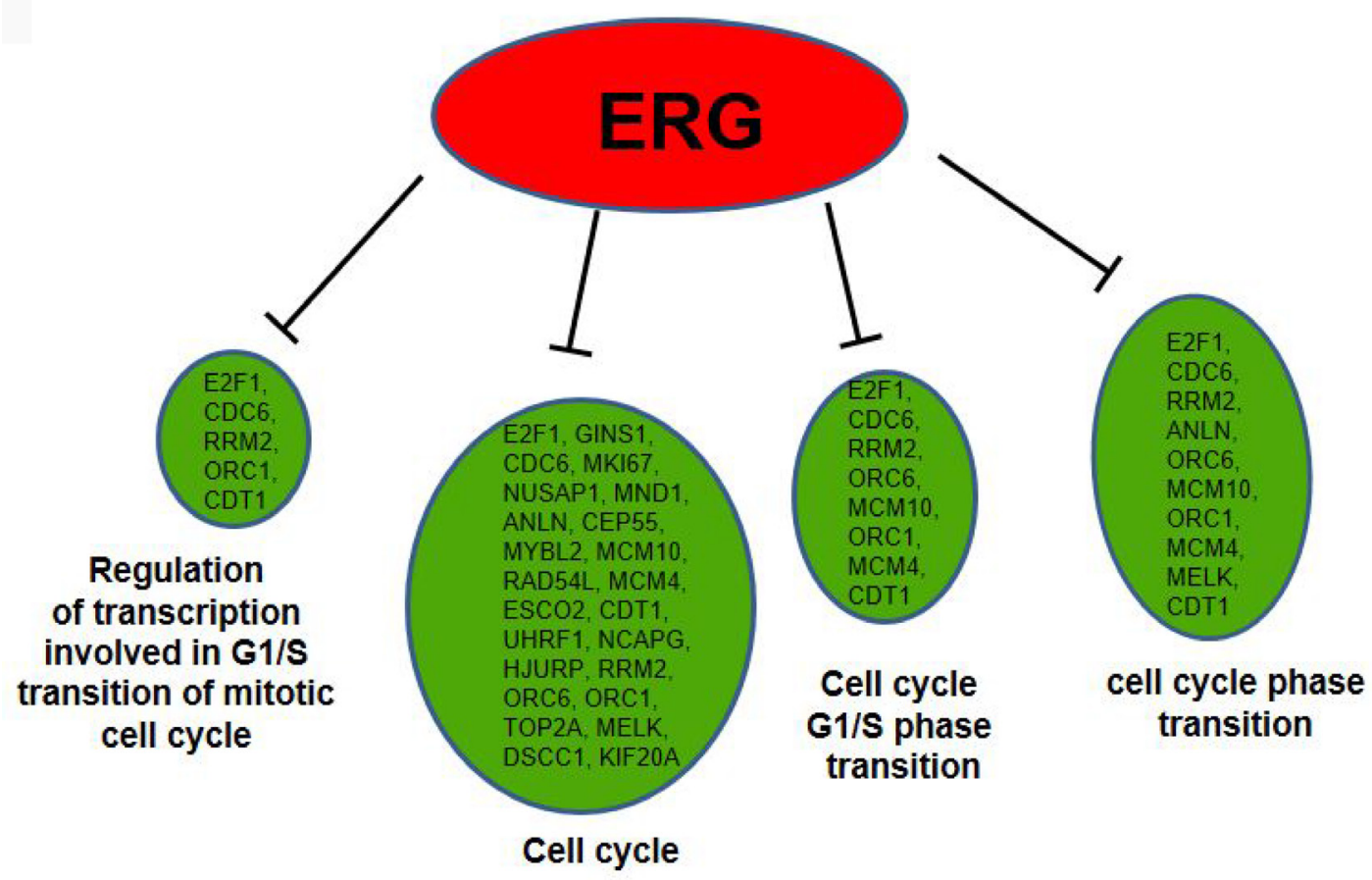

Figure 8: GO term analysis for differentially expressed genes. GO analyses indicate many ERG modulated genes to be associated with regulation of cell cycle, Cell cycle G1/S phase transition, Regulation of transcription involved in G1/S transition of mitotic cell cycle and cell cycle transition (red color represents up-regulated and green color represents down-regulated genes). 
samples were reverse-transcribed using High Capacity cDNA Reverse Transcription Kit (Applied Biosystems, 4368813). Real time quantifications of TMPRSS2-ERG fusion mRNA was performed with specific TaqMan gene expression assay (Assay ID: Hs03063375_ft). Real-time PCR data were normalized to the endogenous control $\beta$-actin. The relative fold changes of candidate genes were analyzed by using $2^{-\Delta \Delta \mathrm{CT}}$ method.

Protein extraction and immunoblot analysis were performed using the standard protocol. In brief, cells were lysed in RIPA buffer supplemented with protease/phosphatase inhibitors (Sigma, P5726 and S8820, respectively). Samples containing $10 \mu \mathrm{g}$ protein were electrophoresed on a 4-12\% Tris-Glycine gel. The separated proteins were electro-transferred to a nitrocellulose membrane (Bio-Rad, 1620112) for western blot analysis. All primary antibodies were used at 1:1000 dilution. The band intensities representing different protein expression levels were quantitated with reference to Glyceraldehyde 3-phosphate dehydrogenase (GAPDH) control bands. The intensities of protein bands were quantitated using ImageJ Gel Analysis program.

\section{Cell cycle and cell proliferation analysis}

LnTE3 cells treated with or without doxycycline for $24 \mathrm{~h}$ and washed with PBS followed by trypsinization, and resuspended as a single cell suspension in PBS. Cells were fixed with $70 \%$ ethanol at a density of $1 \mathrm{million} / \mathrm{ml}$ and stored at $4^{\circ} \mathrm{C}$ for at least overnight. Fixed cells were again washed with PBS, treated with $200 \mu \mathrm{g} / \mathrm{ml}$ RNase-A for $30 \mathrm{~min}$ at $37^{\circ} \mathrm{C}$. These cells are stained with $50 \mu \mathrm{g} / \mathrm{mL}$ propidium iodide and incubated at $4^{\circ} \mathrm{C}$ for $10 \mathrm{~min}$. Cell cycle distribution was studied with the help of BD LSR II (Becton-Dickinson \& CO., USA) flow cytometer. Cell proliferation was performed using Promega's Cell Titer Aqueous kit. Briefly, $1 \times 10^{4}$ LnTE3 cells/well were seeded in a 96-well plate with and without dox and incubated for $24 \mathrm{~h}$. Subsequently after ensuring proper cell adhesion, media was changed, with and without dox as per requirement. The absorbance at $490 \mathrm{~nm}$ was measured using a microplate reader (BMG labtech) from 2 to 5 days interval.

\section{Abbreviations}

RNA-seq: RNA sequencing; UTR: Untranslated Region; CaP: Prostate Cancer; ERG: V-Ets Avian Erythroblastosis Virus E26 Oncogene Homolog; AR: Androgen Receptor; TMPRSS2: Transmembrane Protease Serine2; IPA: Ingenuity Pathway Analysis.

\section{ACKNOWLEDGMENTS}

We thank Taduru Sreenath (USUHS/CPDR) for generously providing ERG-inducible LNCaP cell lines.

\section{CONFLICTS OF INTEREST}

All authors have no conflicts of interest in this study.

\section{GRANT SUPPORT}

This study was supported by the John P. Murtha Cancer Center, Walter Reed-Bethesda, USA.

\section{REFERENCES}

1. Taylor BS, Schultz N, Hieronymus H, Gopalan A, Xiao Y, Carver BS, Arora VK, Kaushik P, Cerami E, Reva B, Antipin Y, Mitsiades N, Landers T, et al. Integrative genomic profiling of human prostate cancer. Cancer Cell. 2010; 18:1122. https://doi.org/10.1016/j.ccr.2010.05.026. [PubMed]

2. Kumar P, Sharad S, Petrovics G, Mohamed A, Dobi A, Sreenath TL, Srivastava S, Biswas R. Loss of miR-449a in ERG-associated prostate cancer promotes the invasive phenotype by inducing SIRT1. Oncotarget. 2016; 7:22791806. https://doi.org/10.18632/oncotarget.8061. [PubMed]

3. Brawley OW. Trends in prostate cancer in the United States. J Natl Cancer Inst Monogr. 2012; 2012:152-56. https://doi. org/10.1093/jncimonographs/lgs035. [PubMed]

4. Madu CO, Lu Y. Novel diagnostic biomarkers for prostate cancer. J Cancer. 2010; 1:150-77. https://doi.org/10.7150/ jca.1.150. [PubMed]

5. Petrovics G, Liu A, Shaheduzzaman S, Furusato B, Sun C, Chen Y, Nau M, Ravindranath L, Chen Y, Dobi A, Srikantan V, Sesterhenn IA, McLeod DG, et al. Frequent overexpression of ETS-related gene-1 (ERG1) in prostate cancer transcriptome. Oncogene. 2005; 24:3847-52. https:// doi.org/10.1038/sj.onc.1208518. [PubMed]

6. Mani RS, Amin MA, Li X, Kalyana-Sundaram S, Veeneman BA, Wang L, Ghosh A, Aslam A, Ramanand SG, Rabquer BJ, Kimura W, Tran M, Cao X, et al. InflammationInduced Oxidative Stress Mediates Gene Fusion Formation in Prostate Cancer. Cell Rep. 2016; 17:2620-31. https://doi. org/10.1016/j.celrep.2016.11.019. [PubMed]

7. Latysheva NS, Babu MM. Discovering and understanding oncogenic gene fusions through data intensive computational approaches. Nucleic Acids Res. 2016; 44:4487-503. https:// doi.org/10.1093/nar/gkw282. [PubMed]

8. Eguchi FC, Faria EF, Scapulatempo Neto C, LongattoFilho A, Zanardo-Oliveira C, Taboga SR, Campos SG. The role of TMPRSS2:ERG in molecular stratification of $\mathrm{PCa}$ and its association with tumor aggressiveness: a study in Brazilian patients. Sci Rep. 2014; 4:5640. https://doi. org/10.1038/srep05640. [PubMed]

9. St John J, Powell K, Conley-Lacomb MK, Chinni SR. TMPRSS2-ERG Fusion Gene Expression in Prostate Tumor Cells and Its Clinical and Biological Significance in Prostate Cancer Progression. J Cancer Sci Ther. 2012; 4:94 101. https://doi.org/10.4172/1948-5956.1000119. [PubMed] 
10. Rubin MA, De Marzo AM. Molecular genetics of human prostate cancer. Mod Pathol. 2004; 17:380-8. https://doi. org/10.1038/modpathol.3800051. [PubMed]

11. Ruggero D. Translational control in cancer etiology. Cold Spring Harb Perspect Biol. 2013; 5:a012336. https://doi. org/10.1101/cshperspect.a012336. [PubMed]

12. Wang Z, Gerstein M, Snyder M. RNA-Seq: a revolutionary tool for transcriptomics. Nat Rev Genet. 2009; 10:57-63. https://doi.org/10.1038/nrg2484. [PubMed]

13. Ren S, Peng Z, Mao JH, Yu Y, Yin C, Gao X, Cui Z, Zhang J, Yi K, Xu W, Chen C, Wang F, Guo X, et al. RNAseq analysis of prostate cancer in the Chinese population identifies recurrent gene fusions, cancer-associated long noncoding RNAs and aberrant alternative splicings. Cell Res. 2012; 22:806-21. https://doi.org/10.1038/cr.2012.30. [PubMed]

14. Young A, Berry R, Holloway AF, Blackburn NB, Dickinson JL, Skala M, Phillips JL, Brettingham-Moore KH. RNA-seq profiling of a radiation resistant and radiation sensitive prostate cancer cell line highlights opposing regulation of DNA repair and targets for radiosensitization. BMC Cancer. 2014; 14:808. https://doi.org/10.1186/14712407-14-808. [PubMed]

15. Pflueger D, Terry S, Sboner A, Habegger L, Esgueva R, Lin PC, Svensson MA, Kitabayashi N, Moss BJ, MacDonald TY, Cao X, Barrette T, Tewari AK, et al. Discovery of non-ETS gene fusions in human prostate cancer using next-generation RNA sequencing. Genome Res. 2011; 21:56-67. https://doi.org/10.1101/gr.110684.110. [PubMed]

16. Sreenath TL, Macalindong SS, Mikhalkevich N, Sharad S, Mohamed A, Young D, Borbiev T, Xavier C, Gupta R, Jamal M, Babcock K, Tan SH, Nevalainen MT, et al. ETS Related Gene mediated Androgen Receptor Aggregation and Endoplasmic Reticulum Stress in Prostate Cancer Development. Sci Rep. 2017; 7:1109. https://doi. org/10.1038/s41598-017-01187-4. [PubMed]

17. Nwosu V, Carpten J, Trent JM, Sheridan R. Heterogeneity of genetic alterations in prostate cancer: evidence of the complex nature of the disease. Hum Mol Genet. 2001; 10:2313-18. https://doi.org/10.1093/hmg/10.20.2313. [PubMed]

18. Brase JC, Johannes M, Mannsperger H, Fälth M, Metzger J, Kacprzyk LA, Andrasiuk T, Gade S, Meister M, Sirma H, Sauter G, Simon R, Schlomm T, et al. TMPRSS2-ERG -specific transcriptional modulation is associated with prostate cancer biomarkers and TGF- $\beta$ signaling. BMC Cancer. 2011; 11:507. https://doi.org/10.1186/1471-240711-507. [PubMed]

19. Amiry N, Kong X, Muniraj N, Kannan N, Grandison PM, Lin J, Yang Y, Vouyovitch CM, Borges S, Perry JK, Mertani HC, Zhu T, Liu D, Lobie PE. Trefoil factor-1 (TFF1) enhances oncogenicity of mammary carcinoma cells. Endocrinology. 2009; 150:4473-83. https://doi. org/10.1210/en.2009-0066. [PubMed]

20. Perry JK, Kannan N, Grandison PM, Mitchell MD, Lobie PE. Are trefoil factors oncogenic? Trends Endocrinol
Metab. 2008; 19:74-81. https://doi.org/10.1016/j. tem.2007.10.003. [PubMed]

21. Radiloff DR, Wakeman TP, Feng J, Schilling S, Seto E, Wang XF. Trefoil factor 1 acts to suppress senescence induced by oncogene activation during the cellular transformation process. Proc Natl Acad Sci USA. 2011; 108:6591-96. https://doi.org/10.1073/pnas.1017269108. [PubMed]

22. Vestergaard EM, Nexø E, Torring N, Borre M, Orntoft TF, Sorensen KD. Promoter hypomethylation and upregulation of trefoil factors in prostate cancer. Int J Cancer. 2010; 127:1857-65. https://doi.org/10.1002/ijc.25209. [PubMed]

23. Bougen NM, Amiry N, Yuan Y, Kong XJ, Pandey V, Vidal LJ, Perry JK, Zhu T, Lobie PE. Trefoil factor 1 suppression of E-CADHERIN enhances prostate carcinoma cell invasiveness and metastasis. Cancer Lett. 2013; 332:1929. https://doi.org/10.1016/j.canlet.2012.12.012. [PubMed]

24. May FE, Westley BR. TFF3 is a valuable predictive biomarker of endocrine response in metastatic breast cancer. Endocr Relat Cancer. 2015; 22:465-79. https://doi. org/10.1530/ERC-15-0129. [PubMed]

25. Vestergaard EM, Borre M, Poulsen SS, Nexo E, Torring N. Plasma levels of trefoil factors are increased in patients with advanced prostate cancer. Clin Cancer Res. 2006; 12:807-12. https://doi.org/10.1158/1078-0432.CCR-05-1545. [PubMed]

26. Arumugam T, Logsdon CD. S100P: a novel therapeutic target for cancer. Amino Acids. 2011; 41:893-99. https:// doi.org/10.1007/s00726-010-0496-4. [PubMed]

27. Averboukh L, Liang P, Kantoff PW, Pardee AB. Regulation of S100P expression by androgen. Prostate. 1996; 29:350-55. https://doi.org/10.1002/(SICI)10970045(199612)29:6<350::AID-PROS2>3.0.CO;2-C. [PubMed]

28. Basu GD, Azorsa DO, Kiefer JA, Rojas AM, Tuzmen S, Barrett MT, Trent JM, Kallioniemi O, Mousses S. Functional evidence implicating S100P in prostate cancer progression. Int J Cancer. 2008; 123:330-39. https://doi. org/10.1002/ijc.23447. [PubMed]

29. Grebhardt S, Veltkamp C, Ströbel P, Mayer D. Hypoxia and HIF-1 increase S100A8 and S100A9 expression in prostate cancer. Int J Cancer. 2012; 131:2785-94. https:// doi.org/10.1002/ijc.27591. [PubMed]

30. Ohara S, Oue N, Matsubara A, Mita K, Hasegawa Y, Hayashi T, Usui T, Amatya VJ, Takeshima Y, Kuniyasu H, Yasui W. Reg IV is an independent prognostic factor for relapse in patients with clinically localized prostate cancer. Cancer Sci. 2008; 99:1570-77. https://doi.org/10.1111/ j.1349-7006.2008.00846.x. [PubMed]

31. Gu Z, Rubin MA, Yang Y, Deprimo SE, Zhao H, Horvath S, Brooks JD, Loda M, Reiter RE. Reg IV: a promising marker of hormone refractory metastatic prostate cancer. Clin Cancer Res. 2005; 11:2237-43. https://doi. org/10.1158/1078-0432.CCR-04-0356. [PubMed]

32. Wang H, Hu L, Zang M, Zhang B, Duan Y, Fan Z, Li J, Su L, Yan M, Zhu Z, Liu B, Yang Q. REG4 promotes 
peritoneal metastasis of gastric cancer through GPR37. Oncotarget. 2016; 7:27874-88. https://doi.org/10.18632/ oncotarget.8442. [PubMed]

33. He XJ, Jiang XT, Ma YY, Xia YJ, Wang HJ, Guan TP, Shao QS, Tao HQ. REG4 contributes to the invasiveness of pancreatic cancer by upregulating MMP-7 and MMP9. Cancer Sci. 2012; 103:2082-91. https://doi.org/10.1111/ cas.12018. [PubMed]

34. Guo Y, Xu J, Li N, Gao F, Huang P. RegIV potentiates colorectal carcinoma cell migration and invasion via its CRD domain. Cancer Genet Cytogenet. 2010; 199:38-44. https://doi.org/10.1016/j.cancergencyto.2010.01.011. [PubMed]

35. Fang Y, Yi J, Lizhi L, Qiucheng C. Rho GDP dissociation inhibitor beta promotes cell proliferation and invasion by modulating the AKT pathway in hepatocellular carcinoma. DNA Cell Biol. 2014; 33:781-86. https://doi.org/10.1089/ dna.2014.2545. [PubMed]

36. Yi B, Hu Y, Qin G, Gu W, Zhu X, He S, Zhou J, Li D. Depletion of RhoGDI2 expression inhibits the ability of invasion and migration in pancreatic carcinoma. Int J Mol Med. 2014; 34:205-12. https://doi.org/10.3892/ ijmm.2014.1765. [PubMed]

37. Cho HJ, Park SM, Kim IK, Nam IK, Baek KE, Im MJ, Yoo JM, Park SH, Ryu KJ, Han HT, Kim HJ, Hong SC, Kim KD, et al. RhoGDI2 promotes epithelial-mesenchymal transition via induction of Snail in gastric cancer cells. Oncotarget. 2014; 5:1554-64. https://doi.org/10.18632/ oncotarget.1733. [ [PubMed]

38. Bizzarro V, Belvedere R, Migliaro V, Romano E, Parente L, Petrella A. Hypoxia regulates ANXA1 expression to support prostate cancer cell invasion and aggressiveness. Cell Adh Migr. 2017; 11:247-260. https://doi.org/10.1080/19336918 .2016.1259056. [ [PubMed]

39. Bizzarro V, Belvedere R, Milone MR, Pucci B, Lombardi R, Bruzzese F, Popolo A, Parente L, Budillon A, Petrella A. Annexin A1 is involved in the acquisition and maintenance of a stem cell-like/aggressive phenotype in prostate cancer cells with acquired resistance to zoledronic acid. Oncotarget. 2015; 6:25076-92. https://doi.org/10.18632/ oncotarget.4725. [PubMed]

40. Chan HS, Chang SJ, Wang TY, Ko HJ, Lin YC, Lin KT, Chang KM, Chuang YJ. Serine protease PRSS23 is upregulated by estrogen receptor $\alpha$ and associated with proliferation of breast cancer cells. PLoS One. 2012; 7:e30397. https://doi.org/10.1371/journal.pone.0030397. [PubMed]

41. Prager AJ, Peng CR, Lita E, McNally D, Kaushal A, Sproull M, Compton K, Dahut WL, Figg WD, Citrin D, Camphausen KA. Urinary aHGF, IGFBP3 and OPN as diagnostic and prognostic biomarkers for prostate cancer. Biomark Med. 2013; 7:831-41. https://doi.org/10.2217/ bmm.13.112. [PubMed]
42. Johanneson B, McDonnell SK, Karyadi DM, Quignon P, McIntosh L, Riska SM, FitzGerald LM, Johnson G, Deutsch K, Williams G, Tillmans LS, Stanford JL, Schaid DJ, et al. Family-based association analysis of 42 hereditary prostate cancer families identifies the Apolipoprotein L3 region on chromosome 22q12 as a risk locus. Hum Mol Genet. 2010; 19:3852-62. https://doi. org $/ 10.1093 / \mathrm{hmg} / \mathrm{ddq} 283$. [PubMed]

43. Paulo P, Ribeiro FR, Santos J, Mesquita D, Almeida M, Barros-Silva JD, Itkonen $\mathrm{H}$, Henrique R, Jerónimo C, Sveen A, Mills IG, Skotheim RI, Lothe RA, Teixeira MR. Molecular subtyping of primary prostate cancer reveals specific and shared target genes of different ETS rearrangements. Neoplasia. 2012; 14:600-11. https://doi. org/10.1593/neo.12600. [PubMed]

44. Rahim S, Minas T, Hong SH, Justvig S, Çelik H, Kont YS, Han J, Kallarakal AT, Kong Y, Rudek MA, Brown ML, Kallakury B, Toretsky JA, Üren A. A small molecule inhibitor of ETV1, YK-4-279, prevents prostate cancer growth and metastasis in a mouse xenograft model. PLoS One. 2014; 9:e114260. https://doi.org/10.1371/journal. pone.0114260. [PubMed]

45. Akamatsu S, Takata R, Haiman CA, Takahashi A, Inoue T, Kubo M, Furihata M, Kamatani N, Inazawa J, Chen GK, Le Marchand L, Kolonel LN, Katoh T, et al. Common variants at 11q12, 10q26 and 3p11.2 are associated with prostate cancer susceptibility in Japanese. Nat Genet. 2012; 44:426-9, S1. https://doi.org/10.1038/ng.1104. [PubMed]

46. Peng M, Wang Z, Yang Z, Tao L, Liu Q, Yi LU, Wang X. Overexpression of short TRPM8 variant $\alpha$ promotes cell migration and invasion, and decreases starvation-induced apoptosis in prostate cancer LNCaP cells. Oncol Lett. 2015; 10:1378-84. https://doi.org/10.3892/ol.2015.3373. [PubMed]

47. Tevz G, McGrath S, Demeter R, Magrini V, Jeet V, Rockstroh A, McPherson S, Lai J, Bartonicek N, An J, Batra J, Dinger ME, Lehman ML, et al. Identification of a novel fusion transcript between human relaxin-1 (RLN1) and human relaxin-2 (RLN2) in prostate cancer. Mol Cell Endocrinol. 2016; 420:159-68. https://doi.org/10.1016/j. mce.2015.10.011. [ $\underline{\text { PubMed] }}$

48. Henshall SM, Afar DE, Rasiah KK, Horvath LG, Gish K, Caras I, Ramakrishnan V, Wong M, Jeffry U, Kench JG, Quinn DI, Turner JJ, Delprado W, et al. Expression of the zinc transporter $\mathrm{ZnT} 4$ is decreased in the progression from early prostate disease to invasive prostate cancer. Oncogene. 2003; 22:6005-12. https://doi.org/10.1038/sj.onc.1206797. [PubMed]

49. Elmore S. Apoptosis: a review of programmed cell death. Toxicol Pathol. 2007; 35:495-516. https://doi. org/10.1080/01926230701320337. [PubMed]

50. Cairns RA, Harris IS, Mak TW. Regulation of cancer cell metabolism. Nat Rev Cancer. 2011; 11:85-95. https://doi. org/10.1038/nrc2981. [PubMed] 
51. Bertoli C, Skotheim JM, de Bruin RA. Control of cell cycle transcription during G1 and S phases. Nat Rev Mol Cell Biol. 2013; 14:518-28. https://doi.org/10.1038/nrm3629. [PubMed]

52. Machida YJ, Teer JK, Dutta A. Acute reduction of an origin recognition complex (ORC) subunit in human cells reveals a requirement of ORC for Cdk2 activation. J Biol Chem. 2005; 280:27624-30. https://doi.org/10.1074/jbc. M502615200. [ubMed]

53. Borlado LR, Méndez J. CDC6: from DNA replication to cell cycle checkpoints and oncogenesis. Carcinogenesis. 2008; 29:237-43. https://doi.org/10.1093/carcin/bgm268. [PubMed]

54. Lunardi A, Varmeh S, Chen M, Taulli R, Guarnerio J, Ala U, Seitzer N, Ishikawa T, Carver BS, Hobbs RM, Quarantotti V, Ng C, Berger AH, et al. Suppression of CHK1 by ETS Family Members Promotes DNA Damage Response Bypass and Tumorigenesis. Cancer Discov. 2015; 5:550-63. https:// doi.org/10.1158/2159-8290.CD-13-1050. [PubMed]

55. Mochmann LH, Neumann M, von der Heide EK, Nowak V, Kühl AA, Ortiz-Tanchez J, Bock J, Hofmann WK, Baldus CD. ERG induces a mesenchymal-like state associated with chemoresistance in leukemia cells. Oncotarget. 2014; 5:351-62. https://doi.org/10.18632/oncotarget.1449. [PubMed]

56. Ratz L, Laible M, Kacprzyk LA, Wittig-Blaich SM, Tolstov Y, Duensing S, Altevogt P, Klauck SM, Sültmann H. TMPRSS2:ERG gene fusion variants induce TGF- $\beta$ signaling and epithelial to mesenchymal transition in human prostate cancer cells. Oncotarget. 2017; 8:25115-30. https:// doi.org/10.18632/oncotarget.15931. [PubMed]

57. Abbas T, Dutta A. p21 in cancer: intricate networks and multiple activities. Nat Rev Cancer. 2009; 9:400-14. https:// doi.org/10.1038/nrc2657. [PubMed]

58. Bae DS, Cho SB, Kim YJ, Whang JD, Song SY, Park CS, Kim DS, Lee JH. Aberrant expression of cyclin D1 is associated with poor prognosis in early stage cervical cancer of the uterus. Gynecol Oncol. 2001; 81:341-47. https://doi.org/10.1006/gyno.2001.6196. [PubMed]

59. Baretton GB, Klenk U, Diebold J, Schmeller N, Löhrs U. Proliferation- and apoptosis-associated factors in advanced prostatic carcinomas before and after androgen deprivation therapy: prognostic significance of p21/WAF1/ CIP1 expression. Br J Cancer. 1999; 80:546-55. https://doi. org/10.1038/sj.bjc.6690390. [PubMed]

60. Aaltomaa S, Lipponen P, Eskelinen M, Ala-Opas M, Kosma VM. Prognostic value and expression of p21(waf1/cip1) protein in prostate cancer. Prostate. 1999; 39:8-15. https:// doi.org/10.1002/(SICI)1097-0045(19990401)39:1<8::AIDPROS2>3.0.CO;2-N. [PubMed]

61. Cheung TH, Lo KW, Yu MM, Yim SF, Poon CS, Chung TK, Wong YF. Aberrant expression of p21(WAF1/CIP1) and p27(KIP1) in cervical carcinoma. Cancer Lett. 2001;
172:93-98. https://doi.org/10.1016/S0304-3835(01)00624-

3. [PubMed]

62. Jung JM, Bruner JM, Ruan S, Langford LA, Kyritsis AP, Kobayashi T, Levin VA, Zhang W. Increased levels of p21WAF1/Cip1 in human brain tumors. Oncogene. 1995; 11:2021-28. [PubMed]

63. Ferrandina G, Stoler A, Fagotti A, Fanfani F, Sacco R, De Pasqua A, Mancuso S, Scambia G. p21WAF1/CIP1 protein expression in primary ovarian cancer. Int J Oncol. 2000; 17:1231-35. https://doi.org/10.3892/ijo.17.6.1231. [PubMed]

64. Gogada R, Amadori M, Zhang H, Jones A, Verone A, Pitarresi J, Jandhyam S, Prabhu V, Black JD, Chandra D. Curcumin induces Apaf-1-dependent, p21-mediated caspase activation and apoptosis. Cell Cycle. 2011; 10:4128-37. https://doi.org/10.4161/cc.10.23.18292. [PubMed]

65. Gogada R, Prabhu V, Amadori M, Scott R, Hashmi S, Chandra D. Resveratrol induces p53-independent, X-linked inhibitor of apoptosis protein (XIAP)-mediated Bax protein oligomerization on mitochondria to initiate cytochrome c release and caspase activation. J Biol Chem. 2011; 286:28749-60. https://doi.org/10.1074/jbc.M110.202440. [PubMed]

66. Macleod KF, Sherry N, Hannon G, Beach D, Tokino T, Kinzler K, Vogelstein B, Jacks T. p53-dependent and independent expression of p21 during cell growth, differentiation, and DNA damage. Genes Dev. 1995; 9:93544. https://doi.org/10.1101/gad.9.8.935. [PubMed]

67. Cayrol C, Knibiehler M, Ducommun B. p21 binding to PCNA causes G1 and G2 cell cycle arrest in p53-deficient cells. Oncogene. 1998; 16:311-20. https://doi.org/10.1038/ sj.onc.1201543. [PubMed]

68. Bretones G, Delgado MD, León J. Myc and cell cycle control. Biochim Biophys Acta. 2015; 1849:506-16. https:// doi.org/10.1016/j.bbagrm.2014.03.013. [PubMed]

69. Kitaura H, Shinshi M, Uchikoshi Y, Ono T, Iguchi-Ariga SM, Ariga H. Reciprocal regulation via protein-protein interaction between c-Myc and p21(cip1/waf1/sdi1) in DNA replication and transcription. J Biol Chem. 2000; 275:10477-83. https://doi.org/10.1074/jbc.275.14.10477. [PubMed]

70. Sun C, Dobi A, Mohamed A, Li H, Thangapazham RL, Furusato B, Shaheduzzaman S, Tan SH, Vaidyanathan G, Whitman E, Hawksworth DJ, Chen Y, Nau M, et al. TMPRSS2-ERG fusion, a common genomic alteration in prostate cancer activates $\mathrm{C}-\mathrm{MYC}$ and abrogates prostate epithelial differentiation. Oncogene. 2008; 27:5348-53. https://doi.org/10.1038/onc.2008.183. [PubMed]

71. Masters JR. Human cancer cell lines: fact and fantasy. Nat Rev Mol Cell Biol. 2000; 1:233-36. https://doi. org/10.1038/35043102. [PubMed]

72. Kim D, Pertea G, Trapnell C, Pimentel H, Kelley R, Salzberg SL. TopHat2: accurate alignment of transcriptomes in the presence of insertions, deletions and gene fusions. 
Genome Biol. 2013; 14:R36. https://doi.org/10.1186/ gb-2013-14-4-r36. [PubMed]

73. Trapnell C, Roberts A, Goff L, Pertea G, Kim D, Kelley DR, Pimentel H, Salzberg SL, Rinn JL, Pachter L. Differential gene and transcript expression analysis of RNA-seq experiments with TopHat and Cufflinks. Nat Protoc. 2012; 7:562-78. https://doi.org/10.1038/nprot.2012.016. [PubMed]
74. Huang W, Sherman BT, Lempicki RA. Systematic and integrative analysis of large gene lists using DAVID bioinformatics resources. Nat Protoc. 2009; 4:44-57. https://doi.org/10.1038/nprot.2008.211. [PubMed] 